\title{
MATHEMATICS TEACHERS' PERCEPTION ABOUT STEM-BASED LEARNING
}

\author{
Fitri Aida Sari ${ }^{1}$, Dadang Juandi ${ }^{2}$ \\ ${ }^{1}$ Universitas Banten Jaya, Jl. Syekh Moh. Nawawi Albantani, Kec. Curug, Kota Serang, Banten, Indonesia \\ ${ }^{2}$ Universitas Pendidikan Indonesia, Jl. Dr. Setiabudi No.229, Isola, Kec. Sukasari, Kota Bandung, Jawa Barat, \\ Indonesia \\ e-mail: fitriaidasari@unbaja.ac.id
}

\begin{abstract}
STEM has long been developed to produce a generation who is ready to face the challenges of the future era. STEM combines four elements (Science, Technology, Engineering, and Mathematics) in a learning process to make it more meaningful. STEM has been widely applied in developed countries, but in Indonesia, it has received less attention and has not been implemented in the education curriculum. The purpose of this study is to describe teachers' perceptions about the application of STEM, whether it is suitable to be applied in each school where the teacher works, what facilities are needed, and whether it is suitable to be applied during the pandemic Covid-19. This research method used a qualitative descriptive method by distributing open questionnaires to mathematics teachers from various regions. The results showed that most teachers agreed to use STEM in learning mathematics, including its application during the pandemic Covid-19. Besides, many things must be prepared before it can be applied, including the readiness and understanding of teachers regarding STEM, the availability of STEM teaching materials, and the availability of supporting facilities for each student and their ability to use them.
\end{abstract}

Keywords: STEM, mathematics, teacher, education, Covid-19

\begin{abstract}
Abstrak
Pendidikan berbasis STEM telah lama dikembangkan untuk mencetak generasi yang siap menghadapi tantangan di era mendatang. Pendidikan berbasis STEM memadukan empat elemen (Science, Technology, Enginering, dan Mathematics) dalam suatu proses pembelajaran agar menjadi lebih bermakna. Pendidikan berbasis STEM telah banyak diterapkan di negara-negara maju, namun di Indonesia masih kurang mendapat perhatian dan belum diterapkan dalam kurikulum pendidikan. Tujuan dari penelitian ini adalah untuk mendeskripsikan persepsi guru tentang penerapan STEM, apakah cocok untuk diterapkan di sekolah masing-masing tempat guru bekerja, fasilitas apa saja yang dibutuhkan dan apakah cocok untuk diterapkan pada masa pandemi Covid-19. Metode penelitian ini menggunakan metode deskriptif kualitatif dengan menyebarkan angket terbuka kepada guru-guru matematika yang berasal dari berbagai daerah. Hasil penelitian menunjukkan bahwa sebagian besar guru setuju dengan pembelajaran matematika berbasis STEM, termasuk penerapannya pada masa pandemi Covid-19. Disamping itu, banyak hal yang harus dipersiapkan sebelum pembelajaran dapat diterapkan, termasuk kesiapan dan pemahaman guru terkait pembelajaran matematika berbasis STEM, ketersediaan bahan ajar pembelajaran berbasis STEM, serta ketersediaan fasilitas pendukung yang dimiliki setiap siswa serta kemampuan mereka untuk menggunakannya.
\end{abstract}

Kata kunci: STEM, matematika, guru, pendidikan, Covid-19

\section{INTRODUCTION}

In 2020, almost all countries in the world will be hit by an extraordinary disaster. The disaster was in the form of a new pandemic, namely Covid-19 (Corona Virus Disease 2019), which was caused by $n$-Cov SARS-2. The first case of Covid-19 was found around December 2019 in Wuhan City, Hubei Province, China, then declared a global health emergency by WHO on January 30, 2020 (Jahangir, 2020). The report submitted by WHO on 27 May 2020 
confirmed 5,488,825 cases of Covid-19 globally with a death toll of 349,095 . New confirmed cases in the last 24 hours globally reached 84,314 with a death rate of 5,581, complete data can be seen in Table 1 below.

Table 1. Covid-19 Cases in Various Continents (WHO, 2020)

\begin{tabular}{ccc}
\hline Globally & $\mathbf{5 4 8 8} \mathbf{8 2 5}$ cases (84 314) & $\mathbf{3 4 9} \mathbf{0 9 5}$ deaths (5 581) \\
\hline Africa & 85815 cases $(2$ 771) & 2 308 deaths (94) \\
Americas & 2495924 cases $(41$ 427) & 145810 deaths (2071) \\
Eastern Mediterranean & 449590 cases $(10690)$ & 11452 deaths (159) \\
Europe & 2061828 cases $(20124)$ & 176226 deaths (3 013) \\
South-East Asia & 218523 cases $(8$ 250) & 6359 deaths (219) \\
Western Pacific & 176404 cases (1 007) & 6927 deaths (25) \\
\hline
\end{tabular}

As of the end of May 2020, the country with the highest Covid-19 cases to date was the United States with 1,634,010 total confirmed cases and a death toll of 97,529. Furthermore, Brazil with 374,898 total confirmed cases and a death toll of 23,473 , and Russia with a total confirmed case of 370,680 and a death toll of 3,968 . These numbers can change every second because the transmission of the Covid-19 disease from human to human continues to occur. Indonesia is also a country experiencing the Covid-19 pandemic, where there were 23,165 confirmed cases and 1,418 of them died (WHO, 2020).

Various policies have been taken by the Indonesian Government to prevent and break the chain of spreading Covid-19, including policies in the field of education. The President of Indonesia, Joko Widodo, stated that the local government can provide policies to prevent the spread of Covid-19. One of the policies that can be taken is to make changes in the learning process (Kompas, 2020), which is usually done face-to-face at schools and universities, into distance learning which is done online with various technology-based media. Since midMarch 2020, the Indonesian Government has officially closed learning activities at schools, as well as implementing an online learning policy. This policy was carried out with the aim of protecting students from the risk of transmitting Covid-19 (Sintema, 2020).

With the Covid-19 pandemic, the education system in Indonesia is faced with new challenges and is required to be able to adapt, especially in the learning process. Teachers are required to be able to innovate in delivering learning, while students are required to still have to learn even though they are at home. This provides new opportunities for teachers and students to take advantage of technology in the learning process. Based on the results of interviews conducted by researchers with several junior high and high school mathematics teachers from various regions in Indonesia, it is known that during the Covid-19 pandemic, Prima: Jurnal Pendidikan Matematika Vol. 5, No. 1, January 2021, 23-34 
learning was carried out online using a variety of applications. Most teachers use WhatsApp groups to share learning material and communicate. Some teachers use google classroom, because they think that media for learning must be separate from social media, when using WhatsApp, it is feared that students 'concentration will be divided between replying to their friends' chats or listening to what is being done. Some teachers use the Edmodo application, with the consideration that this application can make learning in the form of a time-limited exam simulation. Some teachers also use the zoom and google meet applications with the assumption that learning will be more effective if it is still done face-to-face so that student activities can be more controlled during learning. Meanwhile, a small number of others use the YouTube application.

This is in line with STEM (Science, Technology, Engineering and Mathematics) -based learning, where there are technological elements needed during the learning process. The term STEM was first introduced by the National Science Foundation around 1990. At the beginning of its appearance, the first acronym that was introduced was SMET. Then proposed a change to METS, but this acronym did not get a response from the public because it is similar to one of the baseball clubs in New York. Until finally the term STEM was born (Suwarma et al., 2015). The vision of the program in STEM-based education is focused on student development and research so that it can meet the need for a workforce in local and regional industries that can compete in global markets (Egarievwe, 2015). Currently, STEM-based learning has been applied in various countries such as America and Japan. The goal is for students to master science, mathematics and technology which will be used to handle problems in everyday life related to STEM. STEM-based learning is considered capable of removing traditional barriers built between the four disciplines, by integrating them into a cohesive teaching and learning paradigm so as to provide the best opportunity for students to understand the world holistically (Mustam \& Adnan, 2019).

STEM is not a specific discipline so that all teachers can participate in the planning and implementation of the STEM curriculum. Teachers can discuss ideas that link content to one another, and how a trans-disciplinary problem-solving approach can be used to improve student understanding (Basham et al., 2010). In addition, to apply STEM in current learning, a clear concept is needed related to STEM itself, which includes the material framework that must be developed, the facilities needed, the media used, and how to implement STEM so 
that the expected learning objectives can be achieved by good. Based on these problems, further study is needed regarding what things are needed to implement STEM in learning, whether the facilities needed by teachers are available, and how teachers respond to the application of STEM-based learning in the current Covid-19 pandemic.

\section{METHODS}

The type of research used is descriptive qualitative research, where the actual facts and circumstances related to the learning conditions during the Covid-19 pandemic, the available facilities, and what things are needed in implementing STEM-based learning are clearly described. Respondents in this study were 50 mathematics teachers in various regions in Indonesia. While the research instrument used was an open questionnaire containing 19 questions. To facilitate the distribution of the questionnaire to teachers in various regions, researchers used one of the applications provided by Google, namely the Google Form. Through the google form application, questionnaires can be shared and accessed online by teachers, and teacher answers can be directly accepted and accessed by researchers online after the teacher has finished providing answers to researchers' questions, without having to meet face to face. This certainly answers the challenges of limited research due to the Covid19 epidemic, where there are restrictions on direct face-to-face interactions to prevent the transmission and spread of Covid-19.

After the teacher filled out the questionnaire, the researchers conducted interviews to obtain more complete and accurate data. Interviews were conducted by telephone to each of the selected respondents. After all data is collected, data is grouped, then the data is analyzed and presented, so that a conclusion can be drawn.

\section{RESULTS AND DISCUSSION}

Based on the data obtained, the length of the respondents' tenure is quite varied, $20 \%$ of respondents have worked for 1 year, $20 \%$ of respondents have worked for 2 years, $10 \%$ of respondents have worked for 3 years and $50 \%$ of other respondents have worked for more than 5 years. The last education of respondents consisted of $80 \%$ S1 graduates (bachelor degree) and 20\% S2 graduates (master degree). The domiciles where the respondents teach are scattered from Banten, West Java, and Makassar Provinces. 




Diagram 1. Length of Service of Respondents

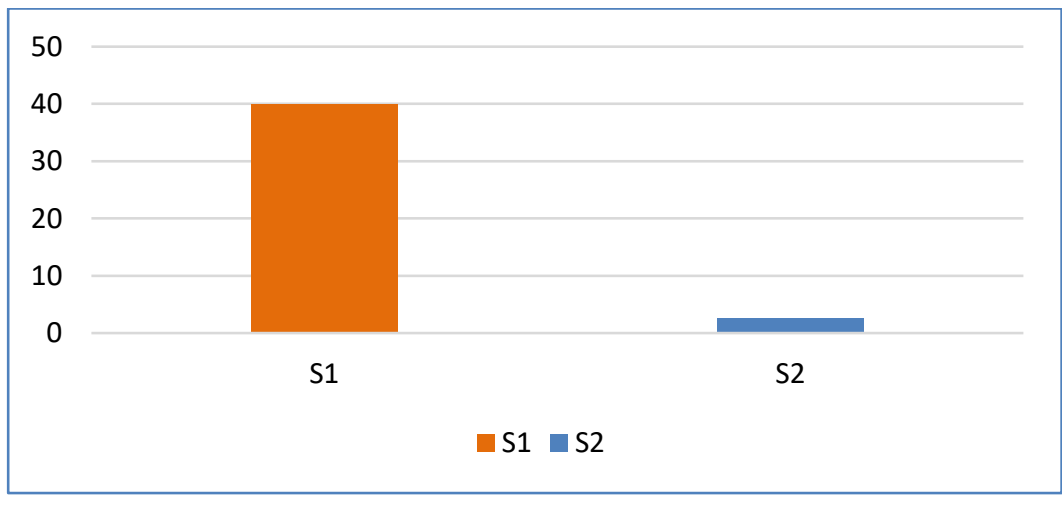

Diagram 2. Respondents' Latest Education

The initial question is related to what training has been attended to analyze whether the teachers have attended training related to the application of STEM. Some of the answers given by the teacher are as follows.

Question: What training have you attended so far?

Teacher's Answer:

Revised Kurtilas (curriculum), making of HOTS problems

Bimtek K-13, PPG in position, and PKP

Curriculum 2013, curriculum 2013 assistance, laboratory training, etc

HOTS and STEM based learning

Mathematics learning seminar, school training

Module, making of problems

STEM learning training by SMEAO, online learning training, scientific publication training, etc

Based on these answers, it is known that the training that is commonly attended by teachers includes training related to the 2013 curriculum, making HOTS questions, and 
making modules. Meanwhile, there are some teachers who claim to have attended STEMbased learning training.

Furthermore, the researcher gave follow-up questions to teachers who had attended the STEM training regarding what material was delivered in the STEM training. Several teachers said that they received material on how to make STEM-based lesson plans and an understanding of the importance of implementing STEM-based learning in schools. Furthermore, to get deeper information regarding teachers' knowledge of STEM, the researcher asked the following questions.

Question: What do you know about STEM education?

Teacher's Answer:

A learning process that combines science, technology, engineering, and mathematics

Saintific Tecnologi Engineering Mathematics

Education using Science, Technology, Engineering, Math

Education that directs students to solve natural environmental problems with the help of technology and use systematic methods

Learning by applying technology

Integration of various sciences, technology, engineering, and mathematics in solving problems or making innovations

STEM is an approach that integrates interdisciplinary knowledge in the learning process

Science and technology-based learning

An integrated learning between science, technology, engineering, and mathematics to develop student creativity through the process of solving problems in daily life

Learning that combines science and technology

The answers presented above illustrate that although most teachers have never attended training related to how to implement STEM-based learning, they may have heard or read information related to the application of STEM in learning. However, the answers presented by the teacher were not entirely correct, there are still teachers who think that the learning they are doing is considered STEM-based learning when the learning is already using technology alone. Meanwhile, a teacher added that STEM learning is learning that combines science and technology. This is in line with the opinion (Lantz, 2009), that many teachers do not realize that STEM-based learning is more than just a new name for traditional learning approaches in science and mathematics learning. Learning is more than just incorporating technological elements into learning. Based on the results of interviews conducted by researchers with teachers, it is known that teachers have considered doing STEM-based mathematics learning when they teach through the microsoft power point application media, 
where the teacher enters teaching materials into the application and then exposes it to the class. The learning that is carried out is still the same, namely the lecture method, giving sample questions, working on practice questions, but what they think is something new and is STEM-based learning is the use of the Microsoft Power Point. The interview data are also in accordance with the teacher's answer as follows.

In the next question, the researcher asks whether STEM has been implemented in the place where the respondent teaches, the answers given by the respondent are as follows.

Question: Has STEM education been implemented in the school where you teach? If so, explain how they are applied!

Answer:

Not yet

Not know

At least already. There is a mathematics subject where learning uses technology-based applications such as three dimensions

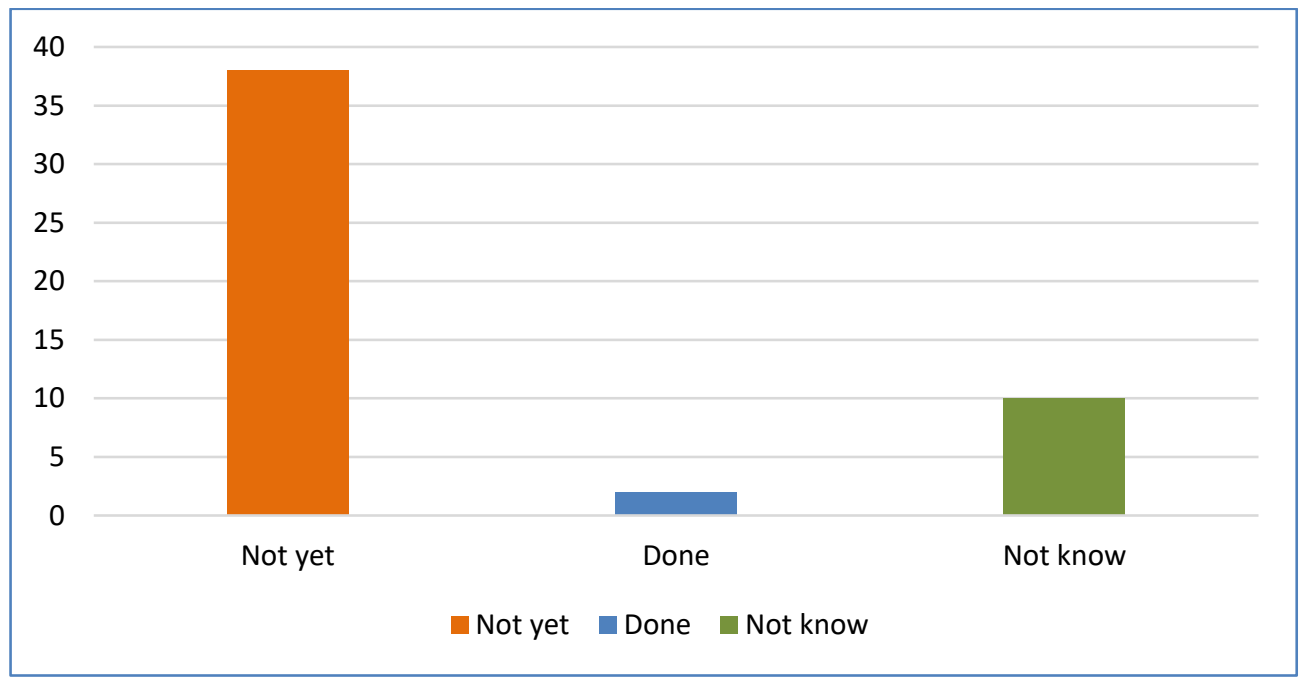

Diagram 3. STEM Application in The Place Where The Respondent Works

Based on Diagram 3, it is known that 48 people stated that they had not implemented STEM, 2 people had applied STEM even though it was only limited to certain material, and 10 other respondents stated that they did not know what STEM was so they had not applied it to the learning that was carried out. Furthermore, the researcher asked questions related to the application of STEM-based learning during the Covid-19 Pandemic. How the teacher's opinion on this is presented in the following data. 
Question: During a Covid-19 pandemic like this, is STEM-based learning suitable to be applied? Explain!

Answer:

Suitable, today's world is heading for automation, which means that the role of humans is being replaced by AI

Not suitable

In the current pandemic condition, in the school where I teach there are many students who don't have gadgets and many students live in remote areas, so STEM is not suitable for implementation

Suitable if all the facilities support

Compatible with the help of technology

Suitable but must be supported by adequate facilities for both teachers and students

Yes, you can use the internet network and facilities such as wifi and laptop

It is suitable because during the Covid-19 pandemic teachers used online learning that led to technology

Probably, but not completely



Diagram 4. Application of STEM During The Covid-19 Pandemic

Most of the teachers stated that STEM-based learning was suitable to be applied during the Covid-19 pandemic as is currently happening. They argue that STEM-based learning is in line with the policies taken by the government to implement online learning. Meanwhile, there are teachers who think that STEM is not suitable for implementation, because there are still many students who do not have supporting facilities such as laptops, cellphones, and internet services. This needs to be studied further, because based on the data submitted by (Kominfo, 2012), Indonesia ranks third in Asia based on the number of Internet users.

Even if viewed by age, the growth of internet users from the age of 10-20 years has increased significantly. The use of the internet is widely used by young people to access their 
social networks such as Twitter and Facebook. There are at least 44.6 million people in Indonesia who actively use Facebook and as many as 19.5 million Indonesians who use Twitter. We must observe this together, whether it is true that these students do not have supporting facilities in implementing online learning or is it just an excuse to avoid learning activities that they must continue to do during the Covid-19 pandemic. Teachers have big challenges in motivating students to continue to be enthusiastic in learning even though learning is not done face-to-face.

Based on interviews conducted with 20 teachers, it is known that they are greatly helped by the technological aspects of learning, learning cannot be done without the help of various existing technologies. To make students excited about learning, there are many tricks they try to do, starting from making practice questions in the Edmodo application which has a timer (time limit) installed so that students must continue to study according to the learning time as is done in school. Some teachers upload learning videos on the YouTube channel so that students can still listen to teacher explanations online. Some teachers also use the zoom application, where the teacher creates a learning room or class, then students are given an access code to enter the class. When class starts, the teacher will check the attendance of students one by one, after which the teacher explains the material. The teacher can display teaching materials from other applications such as power points or other documents on the screen of each student, where the zoom application has a feature for sharing the screen that is being accessed or opened by the teacher. During the learning process, students are required to turn on the camera so that the teacher can supervise the activities carried out by students.

Furthermore, the researcher asked questions related to what things the teacher needed to prepare if they wanted to implement STEM-based learning.

Question: In your opinion, if the teacher wants to implement STEM-based learning during the Covid-19 Pandemic. What things do teachers need to prepare? Explain!

Answer:

Media and facilities

Learning media, steps/learning methods, assessment/targets to be achieved

Prepare teaching materials for children to practice

First, understand about STEM and know the reasons / benefits for students why they should use STEM in this pandemic 
Based on the results of these answers, it is known that what must be prepared includes teaching materials, learning media, and teachers' understanding of STEM-based learning. This is in line with the opinion (Ejiwale, 2012), that to carry out STEM-based learning, facilities such as tools, materials, and equipment must be equipped so that STEM-based learning activities are more meaningful and realistic. Meanwhile, currently, STEM-based teaching materials are still quite difficult to find in Indonesia. Most of the available teaching materials only discuss one or a part of STEM subjects separately, whereas STEM-based learning should be done in a more connected way between subjects, especially in the context of real problems in everyday life. If this is done, it can make STEM-based learning more relevant for students and teachers, which in turn can also increase student motivation, interest, achievement, and persistence in learning (Honey et al., 2014). In addition, not many teachers understand about STEM-based learning, so further socialization is needed to provide explanations to teachers about STEMbased learning and how to apply it. The media used in STEM-based learning also needs to be well prepared, as well as directing students to be able to understand the material presented. The media used should make it easier for students to learn, not media that makes students even more confused to understand the material they are learning.

\section{CONCLUSION}

The results of this study indicate that almost all mathematics teachers welcomed the application of STEM in mathematics learning during the Covid-19 pandemic. However, there are several things that need to be prepared before implementing STEM-based mathematics learning, including socialization related to STEM, where there are still many teachers who do not know about STEM-based learning. In addition, adequate preparation of teaching materials is needed because for now, STEM-based teaching materials are quite difficult to find and not many researchers and educators have formulated and created STEM-based mathematics teaching materials. Then to implement STEM, especially during the Covid-19 pandemic like today, supporting facilities such as laptops or cellphones and internet access are needed so that further analysis is needed whether students already have all the necessary equipment, if not then the teacher must find the best solution to overcome that matter.

Based on the results of this study, the researcher felt it was necessary to carry out further studies regarding student readiness, including the availability of supporting facilities and the ability of students to take advantage of technology, before STEM-based mathematics 
learning was implemented. Furthermore, the researcher felt the need for outreach to teachers, in the form of trainings and seminars, related to STEM-based mathematics learning. Researchers also realize that teaching materials and research related to STEM-based learning in Indonesia are still very limited, so researchers feel they need to be improved again. However, this is also inseparable from the role and responsibility of the government so that researchers feel the need for support from the government, both through policies and programs to improve the quality of STEM-based learning in Indonesia, in order to face current challenges and to meet needs. a workforce that can compete globally.

\section{REFERENCES}

Basham, J. D., Israel, M., \& Maynard, K. (2010). An Ecological Model of STEM Education: Operationalizing STEM for All. Journal of Special Education Technology, 25(3), 9-19. https://doi.org/10.1177/016264341002500303

Egarievwe, S. U. (2015). Vertical Education Enhancement - A Model for Enhancing STEM Education and Research. Procedia - Social and Behavioral Sciences, 177(July 2014), 336344. https://doi.org/10.1016/j.sbspro.2015.02.354

Ejiwale, J. A. (2012). Facilitating Teaching and Learning Across STEM Fields. Journal of STEM Education: Innovations and Research, 13(3), 87-94. http://ojs.jstem.org/index.php?journal=JSTEM\&page=article\&op=view\&path[]=1711

Honey, M. A., Pearson, G., \& Schweingruber, H. (2014). STEM integration in K-12 education: status, prospects, and an agenda for research. In STEM Integration in K-12 Education: Status, Prospects, and an Agenda for Research. https://doi.org/10.17226/18612

Jahangir, M. A. (2020). Coronavirus (COVID-19): History, Current Knowledge and Pipeline Medications. International Journal of Pharmaceutics \& Pharmacology, 4(1), 1-9. https://doi.org/10.31531/2581-3080.1000140

Kominfo. (2012). Pengguna Internet Indonesia Tertinggi Ketiga di Asia. https://kominfo.go.id/content/detail/2365/pengguna-internet-indonesia-tertinggiketiga-di-asia/0/sorotan_media

Kompas. (2020). Arahan Jokowi untuk Pemda: Liburkan Sekolah hingga Tingkatkan Layanan Pasien Covid-19. https://nasional.kompas.com/read/2020/03/15/14452291/ arahanjokowi-untuk-pemda-liburkan-sekolah-hingga-tingkatkan-layanan-pasien 
Lantz, H. B. (2009). Science, Technology, Engineering, and Mathematics (STEM) Education What Form? What Function? Science Education, 1-11.

Mustam, A. A., \& Adnan, M. (2019). Perception of Primary Mathematics Teachers on STEMoriented Teaching and Learning. Journal of Physics: Conference Series, 1227(1). https://doi.org/10.1088/1742-6596/1227/1/012009

Sintema, E. J. (2020). Effect of COVID-19 on the Performance of Grade 12 Students: Implications for STEM Education. Eurasia Journal of Mathematics, Science and Technology Education, 16(7), 1-6. https://doi.org/10.29333/ejmste/7893

Suwarma, I. R., Astuti, P., \& Endah, E. N. (2015). "Balloon Powered Car" Sebagai Media Pembelajaran Ipa Berbasis Stem (Science, Technology, Engineering, and Mathematics). Prosiding Simposium Nasional Inovasi Dan Pembelajaran Sains 2015, 2015(Snips), 373376. https://doi.org/10.1143/JJAP.49.080215

WHO. (2020). Coronavirus disease COVID-2019. Safety and Risk of Pharmacotherapy, 8(1), 38. https://doi.org/10.30895/2312-7821-2020-8-1-3-8 